\title{
Protection of lodgepole pine from attack by the mountain pine beetle, Dendroctonus ponderosae (Coleoptera: Scolytidae) using high doses of verbenone in combination with nonhost bark volatiles
}

\author{
by John H. Borden ${ }^{1}$, Leslie J. Chong ${ }^{1}$, Tracy J. Earle ${ }^{2}$ and Dezene P.W. Huber ${ }^{3}$
}

\begin{abstract}
We evaluated the antiaggregation pheromone verbenone at low and high doses alone and with a seven-component repellent blend of nonhost angiosperm bark volatiles (NHVs) for their ability to deter attack by the mountain pine beetle, Dendroctonus ponderosae Hopkins. Release devices containing antiaggregants were deployed at 16 points on a $10-\mathrm{m}$ grid in $40 \times 40-\mathrm{m}$ plots near Williams Lake, B.C. in June 2001. In 10 control plots with no antiaggregants, single pheromone-baited trees, at the plot centre were all mass-attacked by the mountain pine beetle by early October, as were $26.6 \%$ of the 432 lodgepole pines within the boundaries of the plots. In contrast, in plots treated with a high dose of verbenone plus NHVs, two of the central, pheromone-baited trees escaped any attack whatsoever, four of 10 plots had no surrounding trees attacked and only $2.1 \%$ of the total of 523 surrounding trees were mass-attacked. Density of attacked and mass-attacked trees was highest within $5 \mathrm{~m}$ of the central baited tree in all treatments, indicating that those beetles that breached the antiaggregant grid were then drawn toward the baited tree. Operational efficacy should thus be improved in the absence of baited trees within a treated area. We conclude that high-dose verbenone plus NHV treatments could be implemented operationally as a minor component of an integrated pest management strategy for large infestations, particularly in a push-pull tactic in which beetles are pushed from one area by the antiaggregant treatment and drawn into another with attractive baits. However, the principal use would be in the short-term protection of small, high-value stands or stands of high ecological or social value.
\end{abstract}

Key words: Coleoptera, Scolytidae, Dendroctonus ponderosae, chemical ecology, verbenone, pest management

Nous avons évalué le phéromone antiagrégation verbenone seul à faibles et à fortes doses et avec un mélange répulsif de sept composants volatiles d'écorce d'angiosperme non-hôtes pour sa capacité à détourner les attaques du dendroctone du pin ponderosa, Dendroctonus ponderosae Hopkins. Les appareils permettant de répandre les antiagrégants ont été déployés sur 16 stations réparties selon un quadrillage de $10 \mathrm{~m}$ dans des parcelles de $40 \times 40 \mathrm{~m}$ situées près de Williams Lake, C.-B., en juin 2001. Dans les 10 parcelles témoins sans antiagrégants, les arbres individuels traités comme appât aux phéromones, situés au centre des parcelles ont tous été attaqués massivement par le dendroctone dès le début d'octobre, ainsi que $26 \%$ des 432 pins lodgepoles retrouvés dans les limites des parcelles. Par contre, dans le cas des parcelles traitées avec une forte dose de verbenone additionné du mélange répulsif, deux des arbres du centre traités comme appât aux phéromones ont échappé à toutes les attaques, quatre des 10 parcelles n'ont eu aucun arbre attaqué et seulement $2,1 \%$ des 523 arbres situés à proximité ont été attaqués massivement. La densité des arbres attaqués et attaqués massivement était plus élevée en deçà de $5 \mathrm{~m}$ de l'arbre appât dans tous les traitements, indiquant que les dendroctones qui ont passé au travers du quadrillage d'antiagrégants ont été attirés par la suite vers l'arbre appât. L'efficacité opérationnelle devrait être en conséquence améliorée en l'absence d'arbres appâts au sein de la zone traitée. Nous concluons que les traitements à forte dose de verbenone additionnée du mélange de répulsif pourraient être implantés au niveau opérationnel en tant qu'élément secondaire de la stratégie de contrôle intégré des ravageurs lors de fortes infestations, particulièrement dans le cas d'une tactique de répulsion-attraction selon laquelle les dendroctones sont poussés hors d'une zone par le traitement aux antiagrégants pour être attirés dans une autre au moyen des appâts. Cependant, l'utilisation principale viserait la protection à court-terme de petits peuplements de grande valeur ou de peuplements ayant une forte valeur écologique ou sociale.

Mots clés: Coléoptères, Scolytidae, Dendroctonus ponderosae, écologie chimique, contrôle des ravageurs par verbenone

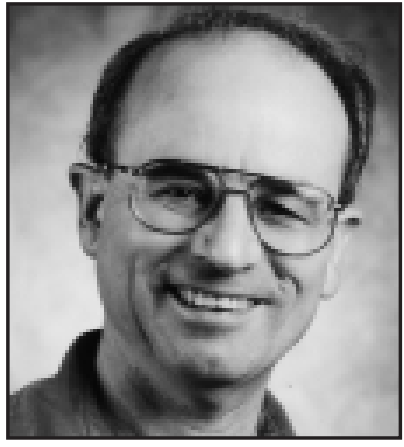

John H. Borden

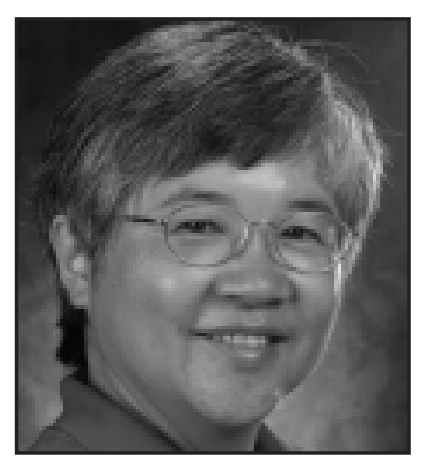

Leslie J. Chong

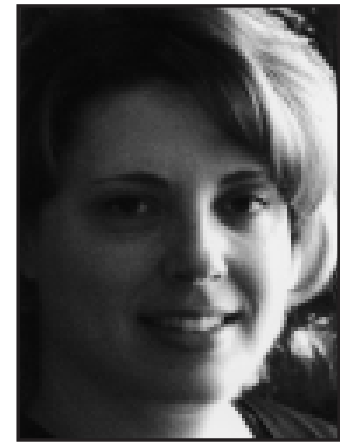

Tracy J. Earle

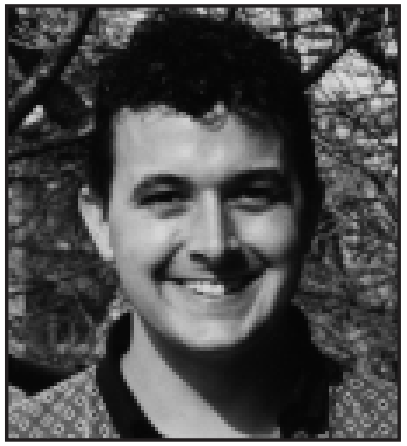

Dezene P. W. Huber

${ }^{1}$ Department of Biological Sciences, Simon Fraser University, 8888 University Drive, Burnaby, BC V5A 1S6. E-mail: borden@sfu.ca

${ }^{2}$ Lignum Ltd., 180 Hodgson Road, Williams Lake, BC V2T 3P6.

${ }^{3}$ Department of Forest Sciences, Faculty of Forestry, University of British Columbia, 2424 Main Mall, Vancouver, BC V6T 1 Z4.

\section{Introduction}

Since the discovery of the terpene ketone verbenone, 4,6,6trimethylbicyclo[3.1.1]hept-3-en-2-one, in the hindguts of the southern pine beetle, Dendroctonus frontalis Zimmerman, and the western pine beetle, D. brevicomis LeConte 
(Renwick 1967), and the finding that verbenone can disrupt the response of $D$. frontalis to traps baited with attractive pheromones (Renwick and Vité 1969), there has been increasing interest in using verbenone to protect coniferous trees from attack by bark beetles (Borden 1997).

In nature verbenone is produced in small amounts by autoxidation of the monoterpene $\alpha$-pinene (Hunt et al. 1989), but the principal route of production is through metabolic conversion by bark beetles of inhaled and ingested $\alpha$-pinene to the terpene alcohols cis- and trans-verbenol, which are then metabolized by yeasts in the beetles' guts and galleries to verbenone (Leufvén et al. 1984; Hunt and Borden 1990). Despite its production by autoxidation and by microorganisms, verbenone is so closely associated with the galleries of bark beetles and is so consistently repellent (to at least 10 species known to date) that it is generally classed as an antiaggregation pheromone or interspecific synomone, inferring that it is produced by the beetles themselves (Borden 1997).

Research on verbenone and its ability to mediate behaviour of the mountain pine beetle, Dendroctonus ponderosae Hopkins, began with its detection in small amounts in the hindguts of emergent and feeding females (Pitman et al. 1969). It is now known to be produced by females alone in new galleries, in reduced amounts by females that have been joined by males in galleries, and in large amounts by the newly-paired males (Pureswaran et al. 2000). Ryker and Yandell (1983) showed that verbenone reduced arrestment of male $D$. ponderosae over a source of attractive volatiles in laboratory bioassays, and at a release rate of $0.07 \mathrm{mg} / 24 \mathrm{~h},(-)$-verbenone lowered catches in attractant-baited traps by $78 \%$ and $86 \%$ in forests of ponderosa pine, Pinus ponderosa Laws., and lodgepole pine, $P$. contorta var. latifolia Engelm., respectively. When the release rate of verbenone was raised to $5.0 \mathrm{mg} / 24 \mathrm{~h}$, catches of male and female $D$. ponderosae in traps baited with trans-verbenol, exo-brevicomin and myrcene were reduced by $97 \%$ and $99 \%$, respectively (Schmitz and McGregor 1990).

Given the success of verbenone in reducing catches of $D$. ponderosae in attractant-baited traps, it is not surprising that in doses of $5-50 \mathrm{mg} / 24 \mathrm{~h}$, verbenone reduced the mean attack density on pheromone-baited lodgepole pines from 68.8 attacks $/ \mathrm{m}^{2}$ to 8.1-26.9 attacks $/ \mathrm{m}^{2}$ (Borden and Lindgren 1988), well below the density of $40 / \mathrm{m}^{2}$ required to kill a healthy lodgepole pine (Raffa and Berryman 1983). Moreover, concurrent research in both the USA (Amman et al. 1989) and Canada (Lindgren et al. 1989) showed that application of bubble caps (Phero Tech Inc., Delta, BC) at $10 \mathrm{~m}$ centres, each releasing verbenone at $5.0 \mathrm{mg} / 24 \mathrm{~h}$, in lodgepole pine stands baited with attractive pheromones reduced percentages of available trees infested by $70 \%$ and $54 \%$, respectively. Subsequently, an experiment in which verbenone-impregnated plastic beads (Phero Tech Inc.) were aerially applied to a lodgepole pine stand at a dose of 54 $\mathrm{g}$ of verbenone/ha resulted in a $75 \%$ reduction of new attacks compared to a control stand (Shea et al. 1992). Although these results were encouraging, other experiments yielded results that were inconsistent between years, geographic areas and tree species (Bentz et al. 1989, Lister et al. 1990, Gibson et al. 1991, Shea et al. 1992), and indicated that when exposed to ultraviolet radiation, verbenone breaks down to the behaviourally-inactive compound chrysanthenone (Kostyk et al. 1993). Consequently, verbenone was not adopted for operational use against the mountain pine beetle.
Interest in verbenone was resurrected with the prospect that efficacy in preventing attack by $D$. ponderosae could be improved by combining it with nonhost volatiles from the bark and leaves of angiosperm trees. Wilson et al. (1996) found two green leaf alcohols, $(E)$-2- and (Z)-3-hexen-1-ol to be competitive with verbenone in reducing catches of $D$. ponderosae in attractant-baited traps, and also to reduce attack density on lodgepole pines baited with the pheromones trans-verbenol and exo-brevicomin by $73 \%$ compared to that on pheromonebaited control trees. Other less disruptive green leaf alcohols were 1-hexanol and (Z)-2-hexen-1-ol. Using coupled gas chromatographic-electronantennographic detection analysis (GCEAD), Borden et al. (1998) found four antennally-active compounds, 1-hexanol, benzaldehyde, benzyl alcohol and nonanal in the bark volatiles of trembling aspen, Populus tremuloides Michx. When tested alone and in all possible binary, ternary and quarternary combinations, they disrupted responses by $D$. ponderosae to pheromone-baited traps in a redundant and additive manner, and all four together were competitive with verbenone in reducing attack density on pheromone-baited lodgepole pines.

The list of disruptive nonhost bark volatiles was subsequently expanded to include conophthorin, a generally-repellent bark beetle pheromone found in the bark of black cottonwood, Populus trichocarpa Torr. and Gray, P. tremuloides Michx., bigleaf maple, Acer macrophyllum Pursh, and paper birch, Betula papyrifera Marsh. (Huber et al. 1999), as well as guaiacol, hexanal, (E)-2-hexenal, and salicylaldehyde (Huber et al. 1999, 2000; Huber and Borden 2003). Nonhost volatile blends alone were effective in delaying and reducing attack on pheromone-baited lodgepole pines, but the greatest disruption of attack was achieved when nonhost volatile blends were combined with verbenone (Borden et al. 2000, 2001; Huber and Borden 2001). Only three of 25 pairs of lodgepole pines with an attractive pheromone bait suspended between them had one or both trees mass attacked by $D$. ponderosae when they were treated with bands of devices releasing a potential operational disruptant blend consisting of $(E)$-2-hexen-1-ol, $(Z)$-3-hexen1-ol, benzyl alcohol, guaiacol, nonanal, salicylaldehyde, benzaldehyde, conophthorin and verbenone (Huber and Borden 2001).

Another option for improving the efficacy of verbenone is to increase the release rate. Accordingly, Phero Tech Inc. has developed a proprietary verbenone pouch in which verbenone formulated in a polyurethane gel is released through a plastic membrane at 4-12 times the emission rate achieved with a conventional bubble cap (S. Burke, Phero Tech Inc., 7572 Progress Way, Delta BC V5G 1E9, personal communication).

Our objective was to evaluate the efficacy of verbenone at low and high doses alone and in combination with a nonhost volatile blend for potential operational use in protecting lodgepole pines from attack by the mountain pine beetle.

\section{Methods}

Five treatments (Table 1) were laid out in fifty $40 \times 40$-m plots, with $\geq 50 \mathrm{~m}$ between plots, in 10 randomized complete blocks, all near Williams Lake, in mixed stands of lodgepole pine and Douglas-fir, Pseudotsuga menziesii (Mirb.) Franco. Replicates 1 and 2 (10 plots) were south of the Beaver Valley Road at Bare Ass Lake, $52^{\circ} 26^{\prime} \mathrm{N}, 122^{\circ} 6.5^{\prime} \mathrm{W}$, in a $101-120$-year-old stand. Replicates 3-8 (30 plots) were on the Redeau Lake Road, $52^{\circ} 4^{\prime} \mathrm{N}, 121^{\circ} 43^{\prime} \mathrm{W}$, in a $141-250$-year-old stand. Repli- 
Table 1. Descriptive statistics for 50 experimental plots, each $40 \times 40 \mathrm{~m}$, randomly assigned to one of five treatments in three locations near Williams Lake, B.C., June - October 2001

\begin{tabular}{|c|c|c|c|c|c|c|c|}
\hline \multirow[b]{2}{*}{ Treatment } & \multicolumn{2}{|c|}{ Baited trees } & \multirow{2}{*}{$\begin{array}{c}\text { No. } \\
\text { surrounding } \\
\text { trees } \\
(\bar{\chi} \pm \mathrm{SE})^{\mathbf{b}}\end{array}$} & \multicolumn{2}{|c|}{$\begin{array}{l}\text { Representative } \\
\text { surrounding trees }\end{array}$} & \multirow[b]{2}{*}{$\begin{array}{l}\text { No. plots with } \\
\text { red attack }\end{array}$} & \multirow{2}{*}{$\begin{array}{c}\text { Range in } \\
\text { no. of } \\
\text { red trees }\end{array}$} \\
\hline & No. & 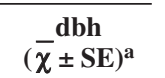 & & No. & $\frac{\mathrm{dbh}}{(\bar{\chi} \pm \mathrm{SE})^{\mathrm{c}}}$ & & \\
\hline Control & 10 & $27.4 \pm 1.5 \mathrm{~b}$ & $43.2 \pm 7.6$ & 50 & $25.0 \pm 0.7 \mathrm{~ns}$ & 4 & $1-3$ \\
\hline Low verbenone & 9 & $29.8 \pm 1.5 \mathrm{ab}$ & $56.1 \pm 5.3$ & 50 & $24.1 \pm 0.6 * *$ & 3 & $1-5$ \\
\hline Low verbenone + NHVs & 10 & $26.5 \pm 1.0 \mathrm{~b}$ & $43.7 \pm 6.3$ & 50 & $24.6 \pm 0.7 \mathrm{~ns}$ & 2 & $1-2$ \\
\hline High verbenone & 10 & $28.6 \pm 0.9 \mathrm{ab}$ & $52.1 \pm 8.6$ & 49 & $26.1 \pm 1.0 \mathrm{~ns}$ & 2 & 1 \\
\hline High verbenone + NHVs & 10 & $33.3 \pm 1.8 \mathrm{a}$ & $52.3 \pm 9.7$ & 50 & $25.9 \pm 0.7 * *$ & 6 & $1-4$ \\
\hline
\end{tabular}

${ }^{\mathrm{a}}$ Means followed by the same letter are not significantly different, REGW-Q test, $P<0.05 . \mathrm{F}=3.70, \mathrm{df}=4, P=0.0112$.

${ }^{\mathrm{b}}$ No difference in number of surrounding trees among treatments, $\mathrm{F}=0.56, \mathrm{df}=4, P=0.6898$.

${ }^{\mathrm{c}}$ No difference in $\mathrm{dbh}$ of representative surrounding trees among treatments, $\mathrm{F}=1.39, \mathrm{df}=4, P=0.2379$. Means followed by $* *$ are significantly lower than means for baited trees in the same treatment, t-test, $P<0.01$. ns $=$ no significant difference, t-test, $P>0.05$.

Table 2. Description of volatile chemicals, release devices and release rates. All compounds and materials from Phero Tech Inc., and release rates determined by the company

\begin{tabular}{|c|c|c|c|}
\hline $\begin{array}{l}\text { Volatile category } \\
\text { and compound } \\
\end{array}$ & $\begin{array}{c}\text { Chemical } \\
\text { purity }(\%)\end{array}$ & Release device and blends & $\begin{array}{c}\text { Release rate } \\
(\mathbf{m g} / \mathbf{2 4} \mathbf{h})\end{array}$ \\
\hline $\begin{array}{l}\text { trans-verbenol } \\
\text { exo-brevicomin }\end{array}$ & $\begin{array}{l}85 \\
97\end{array}$ & $\begin{array}{l}\text { bubble cap } \\
\text { flexlure }\end{array}$ & $\begin{array}{l}0.3 \text { at } 20^{\circ} \mathrm{C} \\
1.2 \text { at } 20^{\circ} \mathrm{C}\end{array}$ \\
\hline $\begin{array}{l}\text { ANTIAGGREGATION PHEROMONE } \\
\text { (-)-verbenone } \\
(80 \% \text { optical purity) }\end{array}$ & $>98$ & $\begin{array}{l}\text { bubble cap } \\
\text { pouch }\end{array}$ & 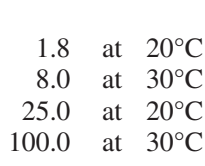 \\
\hline
\end{tabular}

NONHOST ANGIOSPERM BARK

\section{VOLATILES}

guaiacol

benzaldehyde

salicylaldehyde

nonanal

(E)-2-hexen-1-ol

(Z)-3-hexen-1-ol

Benzyl alcohol

$\begin{aligned}>98 & \text { bubble cap } \\ >99 & \text { bubble cap, with salicylaldehyde and nonanal } \\ 99 & \text { bubble cap, with benzaldehyde and nonanal } \\ 95 & \text { bubble cap, with salicylaldehyde and benzaldehyde } \\ 98 & \text { bubble cap, with }(Z)-3 \text {-hexen-1-ol and benzyl alcohol } \\ 98 & \text { bubble cap, with }(E) \text {-2-hexen-1-ol and benzyl alcohol } \\ 98 & \text { bubblecap, with }(E) \text {-2-hexen-1-ol and }(Z) \text {-3-hexen-1-ol }\end{aligned}$

$\begin{array}{lll}5 & \text { at } & 20^{\circ} \mathrm{C} \\ \sim 5 & \text { at } & 20^{\circ} \mathrm{C} \\ \sim 5 & \text { at } & 20^{\circ} \mathrm{C} \\ \sim 5 & \text { at } & 20^{\circ} \mathrm{C} \\ \sim 1.2 & \text { at } & 2{ }^{\circ} \mathrm{C} \\ \sim 1.2 & \text { at } & 2{ }^{\circ} \mathrm{C} \\ \sim 1.2 & \text { at } & 2{ }^{\circ} \mathrm{C}\end{array}$

cates 9 and 10 ( 10 plots) were on the Blue Lake Road, $52^{\circ} 20.5^{\prime} \mathrm{N}$, $122^{\circ} 9.5^{\prime} \mathrm{W}$, in a $121-140$-year-old stand. All three areas had scattered mountain pine beetle infestation, judged to be sufficient to challenge each treatment with large numbers of attacking beetles, but low enough not to overwhelm the treatments.

Each plot was centred on a large-diameter lodgepole pine, $20 \mathrm{~cm}$ minimum diameter at breast height $(\mathrm{dbh}=1.3 \mathrm{~m})$. From 20-22 June 2001 each centre tree was baited with a mountain pine beetle pheromone tree bait (Table 2) stapled to the north aspect of the tree at maximum reach from the ground, and the $\mathrm{dbh}$ of the tree was recorded. Care was taken not to superimpose plots on clumps of trees with red foliage (red trees) that had been attacked in 2000 and were potential sources of emergent brood beetles. However, 17 of the 50 plots had one to five red trees within their boundaries (Table 1).

Control plots received no further treatment. All other plots in a replicate were treated at 16 points on a 10-m grid (Fig. 1) with one of four treatments (Tables 1,2): 1) low-dose verbenone bubble caps, 2) low-dose verbenone bubble caps plus nonhost volatiles (NHVs), 3) high-dose verbenone pouches, and 4) high-dose verbenone pouches plus NHVs. For brevity in tables and figures low-dose and high-dose are shortened to "low" and "high." Devices releasing these materials (Table 2) were stapled on the north aspect of the nearest vertical object, usually a tree.
Lodgepole pines $\geq 17.5 \mathrm{~cm}$ dbh up to $5 \mathrm{~m}$ off-centre were preferentially treated. The NHV blend (Table 2) was similar to the pre-operational blend tested by Huber and Borden (2001), but lacked conophthorin, because the cost of synthesizing it using known routes made it too expensive for potential operational use.

The experiment was evaluated on 5-7 October 2001. The attack density on each baited tree was counted in two $20 \times 40-\mathrm{cm}$ panels at eye level on the east and west aspects of the tree. All surrounding lodgepole pines that were mass-attacked $(\geq 5$ attacks in the two $20 \times 40$-cm panels, or visually determined to be massattacked on the basis of many pitch tubes and copious amounts of frass in bark crevices and around the root collar) were mapped to the nearest metre, as were all trees attacked, but not mass-attacked, and also red trees. All unattacked lodgepole pines $\geq 17.5 \mathrm{~cm}$ dbh were also counted in each plot. Lodgepole pines bearing antiaggregant treatments were included in the tally of surrounding trees. After evaluating trees within each plot the observer proceeded to the nearest plot corner or the nearest point on the closest boundary line and measured the dbh of the nearest five representative lodgepole pines $\geq 17.5 \mathrm{~cm}$ dbh that were encountered outside of the plot within $5 \mathrm{~m}$ of the boundary.

Data for dbh of baited and surrounding trees, attack density on baited trees and numbers of all attacked trees, and those attacked trees that were mass-attacked were analyzed by 


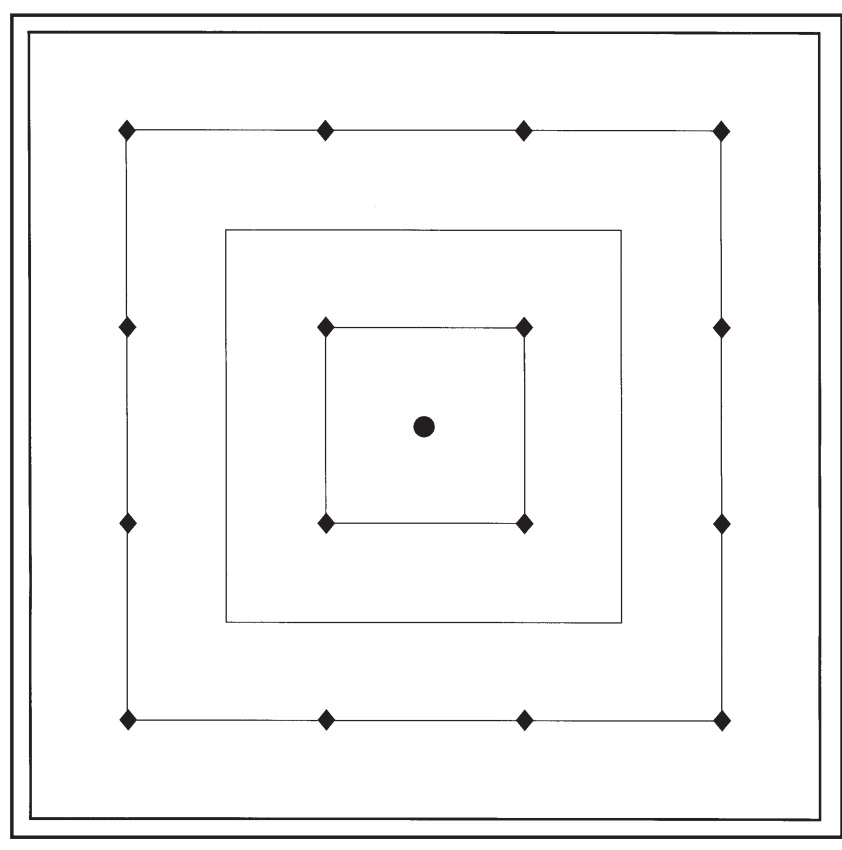

Fig. 1. Layout of $40 \times 40-\mathrm{m}$ plot, showing position of the pheromonebaited tree in the centre (circle) surrounded by a 10-m grid of 16 positions in which antiaggregants were released (diamonds), and concentric 5 -m-wide bands in which attack by $D$. ponderosae was evaluated.

ANOVA, and if $\mathrm{F}$ values were significant, means were compared by the Ryan, Einot, Gabriel, Welsh multiple Q test (Day and Quinn 1989) (SAS Inst. Inc., Ver. 8.01, 1999). One baited tree in the low-dose verbenone treatment was dead when baited and was discounted. Mean dbh's for baited and representative surrounding trees were compared within treatments by t-tests. The pooled proportions of all surrounding trees that were attacked and mass-attacked were compared among treatments by a chi-square test for testing multiple proportions (Zar 1984). In all cases $\alpha=0.05$. The pooled numbers of attacked and mass-attacked trees in bands within 5, 10, 15 and $20 \mathrm{~m}$ of the centre trees (Fig. 1) were plotted by density per $\mathrm{dm}^{2}(10 \times$ $10 \mathrm{~m}$ ) to compare the attack dynamics within the plots among the treatments.

Pre- and post-attack evaluations allowed the characteristics of the treated trees and stands to be described. The mean dbh $( \pm \mathrm{SE})$ of the baited trees ranged from $26.5 \pm 1.0$ in the low-dose verbenone plus NHV treatment to $33.3 \pm 1.8 \mathrm{~cm}$ in the highdose verbenone plus NHV treatment (Table 1). Baited trees in the latter treatment were significantly larger than in the former treatment, as well as the control. In two treatments, low-dose verbenone and high-dose verbenone, the baited trees were significantly larger than those in the 50-tree sample of representative surrounding trees. The mean number of surrounding lodgepole pines per plot ranged from $43.2 \pm 7.6$ to $56.1 \pm 5.3$, corresponding to densities of 270 to 351 per ha. The densities and percentages of red trees within the plots in the three treatment areas were roughly comparable, as follows: $3.1 /$ ha and $1.0 \%$ at Bare Ass Lake, 5.8/ha and 1.6\% at Redeau Road, and $1.9 /$ ha and $1.1 \%$ at Blue Lake Road.

\section{Results}

All 10 baited trees in control plots were mass-attacked, and all 10 control plots had attacked lodgepole pines sur- rounding the baited trees (Table 3 ). Of the 11.5 trees per plot that were attacked in the control plots, an average of 9.2 of those trees was mass-attacked. In contrast, two baited trees in the highdose verbenone plus NHV treatment escaped attack, and in four plots with this treatment, none of the surrounding trees was attacked (Table 3). In the remaining six plots with this treatment the means of all surrounding trees that were attacked and mass-attacked were $75.6 \%$ and $80.4 \%$ lower, respectively, than in the control plots. There was no difference among treatments in attack density on baited trees that were attacked. Two plots in the lowdose verbenone plus NHV treatment had no surrounding trees attacked, as did two plots in the high-dose verbenone treatment. In the remaining plots with these treatments, and in the lowdose verbenone treatment, numbers of surrounding trees attacked and mass-attacked were intermediate between those in the control and high-dose verbenone plus NHV treatments (Table 3).

When the densities of surrounding trees attacked and massattacked per $\mathrm{dm}^{2}$ were pooled within treatments and plotted in concentric $5 \mathrm{~m}$-wide bands around the baited trees (Fig. 1), all treatments showed a high density of infested trees concentrated within $5 \mathrm{~m}$ of the baited trees (Fig. 2). Densities of infested trees in control plots were much lower in the outer three bands than in the innermost bands, but even in the outer band, each plot on average had $\geq 3$ mass-attacked trees. In the low-dose verbenone and low-dose verbenone plus NHV treatments, the attack densities in the outer three bands fell off slightly, but the densities in the inner-most band were as high as or higher than in the control plots, indicating that beetles successfully flew through the antiaggregant grid to attack the baited trees and those immediately around them. In the high-dose verbenone treatment, the densities in the outer three bands were much lower than in the control plots, but those in the innermost band were still high, suggesting some deterrence to entering or remaining in the blocks exerted by the antiaggregant grid. But again, those beetles that did enter were drawn through the grid by the powerful semiochemical lure on the baited trees. Only in the high-dose verbenone plus NHV treatment was the deterrent effect great enough to lower the density of infested trees strikingly in all bands.

The power of the high-dose verbenone plus NHV treatment to deter attack in a treated grid is truly apparent in Fig. 3, which shows that only $3.3 \%$ and $2.1 \%$ of 523 available trees in all 10 blocks pooled were attacked and mass-attacked, respectively. For mass-attacked trees, this proportion was significantly less than for the high-dose verbenone treatment, which in turn was less than for either low-dose verbenone treatment. Adding NHVs to low-dose verbenone did not reduce the proportions of surrounding trees attacked or mass-attacked, and the $15.3 \%$ of available trees that were mass-attacked was not significantly lower than the $21.5 \%$ of mass-attacked trees surrounding baited control trees.

The surrounding trees in the experimental plots included from 72 to 80 lodgepole pines $\geq 17.5 \mathrm{~cm}$ dbh that were treated with antiaggregants. The proportions of treated trees attacked and mass-attacked were similar to those of untreated trees (Table 4). Therefore, in support of the density trends in Fig. 2, the treatments apparently deterred entry into the treated grid, but once within the grid, beetles drawn toward the central baited tree were not deterred from attacking a nearby treated tree. 
Table 3. Effect of treatment with verbenone at two release rates, with and without NHVs on attack by mountain pine beetles on baited and surrounding lodgepole pines in $40 \times 40-\mathrm{m}$ plots

\begin{tabular}{|c|c|c|c|c|c|c|}
\hline \multirow[b]{2}{*}{ Treatment } & \multicolumn{2}{|c|}{ Baited trees } & \multirow{2}{*}{$\begin{array}{l}\text { Attack density/m } \mathbf{m}^{2} \\
\text { on attacked trees } \\
\qquad(\bar{\chi} \pm S E)^{\mathrm{a}}\end{array}$} & \multirow{2}{*}{$\begin{array}{c}\text { No. replicates } \\
\text { with attack on } \\
\text { surrounding trees }\end{array}$} & \multicolumn{2}{|c|}{$\begin{array}{c}\text { When surrounding trees attacked, } \\
\text { no. trees }(\chi \pm S E)\end{array}$} \\
\hline & No. & No. attacked & & & Attacked $^{\text {b }}$ & Mass attacked $^{b}$ \\
\hline Control & 10 & 10 & $118.8 \pm 16.7$ & 10 & $11.5 \pm 2.7 \mathrm{a}$ & $9.2 \pm 2.1 \mathrm{a}$ \\
\hline Low verbenone & 9 & 9 & $157.0 \pm 16.6$ & 9 & $8.8 \pm 1.3 \mathrm{ab}$ & $7.2 \pm 1.1 \mathrm{ab}$ \\
\hline Low verbenone + NHVs & 10 & 9 & $115.3 \pm 16.5$ & 8 & $9.4 \pm 2.2 \mathrm{ab}$ & $8.4 \pm 2.2 \mathrm{ab}$ \\
\hline High verbenone & 10 & 10 & $134.4 \pm 19.0$ & 8 & $5.0 \pm 1.5 \mathrm{ab}$ & $3.9 \pm 1.5 \mathrm{ab}$ \\
\hline High verbenone + NHVs & 10 & 8 & $120.3 \pm 20.7$ & 6 & $2.8 \pm 0.4 b$ & $1.8 \pm 0.6 \mathrm{~b}$ \\
\hline
\end{tabular}

${ }^{a}$ No difference in attack density among baited trees, $\mathrm{F}=0.90, \mathrm{df}=4, P=0.4703$.

${ }^{b}$ Means followed by the same later are not significantly different, REGW-Q test, $P<0.05 . \mathrm{F}=2.97, \mathrm{df}=4, P=0.0321$ for attacked trees, and $\mathrm{F}=2.91, \mathrm{df}=$ 4, $P=0.0347$ for mass attacked trees.

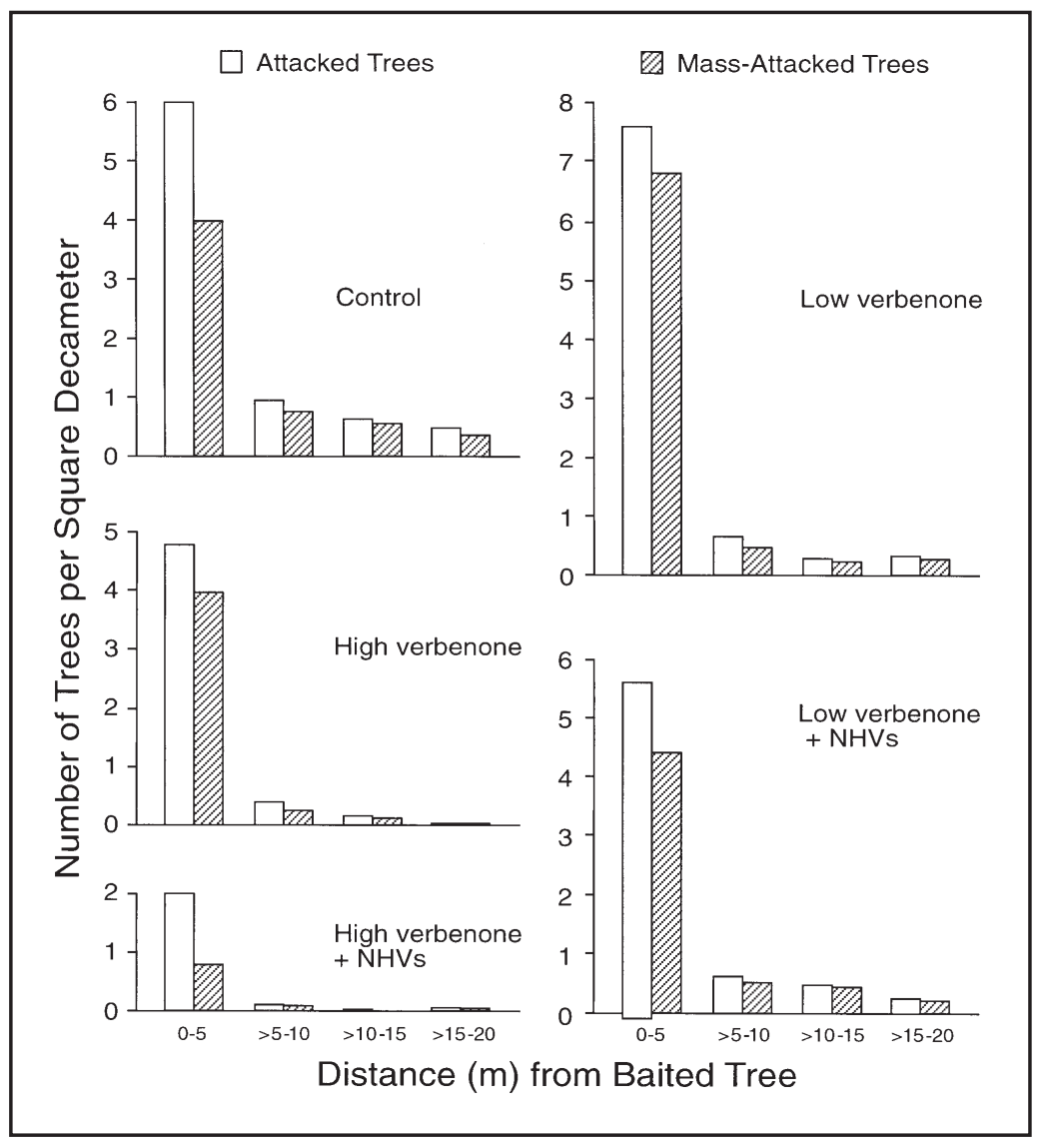

Fig. 2. Density of all pooled attacked and massattacked lodgepole pines per $\mathrm{dm}^{2}(10 \times 10 \mathrm{~m})$ in the fall of 2001 in four concentric 5-m-wide bands around the central pheromone-baited tree in control plots and plots with one of four antiaggregant treatments.

\section{Discussion}

Our results (Fig. 3) indicate that the efficacy of verbenone in protecting lodgepole pines from attack by $D$. ponderosae in a treated area can be increased significantly by increasing the dose of verbenone. They also indicate that efficacy can be increased still further by combining a high dose of verbenone with a NHV blend. Even when the four plots with no surrounding trees attacked in the high dose verbenone plus NHV treatment were discounted, the numbers of attacked and mass-attacked surrounding trees were significantly lower than in the control plots (Table 3). Thus, this treatment remained effective in spite of the potential source of secondary attraction represented by the mass-attacked baited trees. These results expand on those of Wilson et al. (1996), Borden et al. (1998) Shore et al. (1992), and Huber and Borden (2001), who showed that individual and paired baited trees can be protected. These studies also showed that attack on surrounding trees within $5 \mathrm{~m}$ of baited trees can also be reduced, probably because failure of $D$. ponderosae to mass-attack baited trees precluded the emission of beetle-produced pheromones that would have created a focussed attack. It is possible that efficacy would have been even greater in the absence of an attractive central baited tree that challenged beetles to successfully breach the antiaggregant treatments, particularly for the low-dose verbenone treatments (Fig. 3). However, adding NHVs to low-dose verbenone did not improve the efficacy of the antiaggregant grid (Table 3, Fig. 3), and low-dose treatments are not recommended because of their historical variability (Bentz et al. 1989, Lister et al. 1990, Gibson et al. 1991, Shea et al. 1992).

Similar attack frequencies by $D$. ponderosae on antiaggregant-treated and untreated trees within a treated grid (Table 4) probably indicate that once within a treated area in the pres- 
Table 4. Comparison of percentages of attacked and mass-attacked lodgepole pines $\geq 17.5 \mathrm{~cm}$ dbh surrounding the baited trees, that were treated or not treated with antiaggregants

\begin{tabular}{|c|c|c|c|c|c|c|}
\hline \multirow[b]{2}{*}{ Treatment } & \multicolumn{2}{|c|}{ Number } & \multicolumn{2}{|c|}{$\begin{array}{c}\text { Percent of trees } \\
\text { attacked }^{\mathrm{a}}\end{array}$} & \multicolumn{2}{|c|}{$\begin{array}{l}\text { Percent of trees } \\
\text { mass-attacked }^{\mathrm{a}}\end{array}$} \\
\hline & Treated & Untreated & Treated & Untreated & Treated & Untreated \\
\hline Low verbenone & 83 & 478 & 13.3 & 14.2 & 9.7 & 11.9 \\
\hline Low verbenone + NHVs & 74 & 363 & 18.9 & 16.8 & 17.6 & 14.9 \\
\hline High verbenone & 79 & 442 & 6.3 & 7.9 & 6.3 & 5.9 \\
\hline High verbenone + NHVs & 84 & 439 & 4.8 & 3.0 & 3.6 & 1.8 \\
\hline
\end{tabular}

${ }^{a}$ Comparison of treated versus untreated proportions for attacked and mass-attacked trees by chi-square tests within each treatment disclosed no significant differences, max. $\chi^{2}<1.0, P>0.7$.

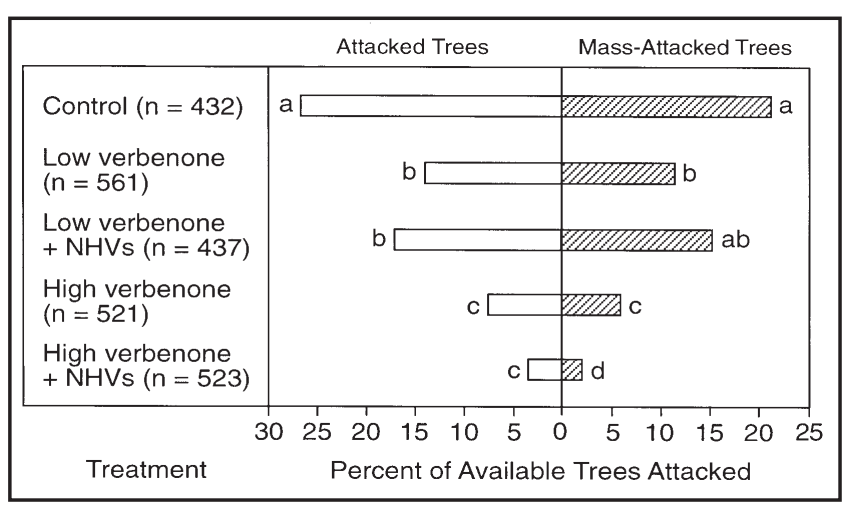

Fig. 3. Comparison of proportions of available lodgepole pines $\geq 17.5$ $\mathrm{cm}$ dbh (nos. in parentheses) surrounding the central baited tree that were attacked and mass-attacked in 2001. Bars with the same letter are not significantly different, chi-square test for multiple proportions, $P<0.05$.

ence of attractive pheromones, a strong visual response to vertical silhouettes (Borden et al. 1986) over-rides any deterrent effect of verbenone and NHVs on individual trees. Therefore, the efficacy of verbenone and NHVs should be best at low population densities when the antiaggregant treatment may prevent enough beetles penetrating a treated area, mass-attacking trees and setting up sources of attraction that would otherwise cause the treatment to fail. This explanation would account for the lack of a significant reduction in attacked trees when Safranyik et al. (1992) allowed a total of 66700 D. ponderosae to emerge from infested logs placed adjacent to five pairs of $50 \times 50$-m plots treated with devices releasing verbenone at $10 \mathrm{mg}$ or $20 \mathrm{mg}$ in a $10-\mathrm{m}$ grid.

Our best result was achieved with a high-dose verbenone plus NHV treatment that apparently excluded beetles from entering a treated grid, or caused them not to be arrested within the grid, and induced those beetles that emerged from the small number of red trees within the plots to disperse out of them. The efficacy of such a "push" tactic would probably be improved if it were combined with pheromone-baited trees to "pull" beetles away from a protected area (Lindgren and Borden 1993). Trees on which attack was induced in the "pull" zone could then be removed by sanitation harvesting or one or more single-tree treatments before the next beetle flight (Maclauchlan and Brooks 1999).

Even without implementation of a push-pull tactic, we recommend high-dose verbenone plus NHV treatments for operational adoption to protect lodgepole pine stands from attack by $D$. ponderosae. Because of the high cost, $\$ 1250 /$ ha for release devices excluding labour, future research must investigate measures to cut costs without sacrificing efficacy, e.g., wider spacing of release devices and reduction in complexity of the NHV blend. In turn, improved manufacturing procedures may lower the unit cost of devices. At present, however, we do not recommend implementation on large timber-production areas, unless antiaggregants are just one of numerous integrated tactics used to satisfy the strategic objective of suppressing a large infestation (Maclauchlan and Brooks 1999). Otherwise, this tactic would be best implemented on a small scale in stands of very high timber value, or in non-timber stands of high social or ecological value for such uses as recreation, water catchment, research and the conservation of natural flora and fauna (Borden 1997).

\section{Acknowledgements}

We thank J.D. Alexander, D. Norman and M. McKinnon for assistance in locating sites and setting up the experiment, and S.A. Campbell and D.S. Pureswaran for assistance in field evaluation. The research was supported by Forest Renewal B.C., The Natural Sciences and Engineering Research Council of Canada, Abitibi Consolidated Inc., Ainsworth Lumber Co. Ltd., B.C. Hydro and Power Authority, Bugbusters Pest Management Inc., Canadian Forest Products Ltd., Gorman Bros Ltd., International Forest Products Ltd., Lignum Ltd., Manning Diversified Forest Products Ltd., Millar-Western Forest Products Ltd., Phero Tech Inc., Riverside Forest Products Ltd., Slocan Forest Products Ltd., Tembec Forest Industries Ltd., TimberWest Ltd., Tolko Industries Ltd., Weldwood of Canada Ltd., West Fraser Mills Ltd., Western Forest Products Ltd., and Weyerhaeuser Canada Ltd.

\section{References}

Amman, G.D., R.W. Their, M.D. McGregor and R.F. Schmitz. 1989. Efficacy of verbenone in reducing lodgepole pine infestation by mountain pine beetles in Idaho. Can. J. For. Res. 19: 60-64.

Bentz, B., C.K. Lister, J.M. Schmid, S.A. Mata, L.A. Rasmussen and D. Haneman. 1989. Does verbenone reduce mountain pine beetle attacks in susceptible stands of ponderosa pine? USDA For. Serv. Res. Note RM-495. 4 p.

Borden, J.H. 1997. Disruption of semiochemical-mediated aggregation in bark beetles (Coleoptera: Scolytidae). In R.T. Cardé and A.K. Minks (eds.). Pheromone research: new directions. pp. 421-438. Chapman and Hall, New York. 684 p.

Borden, J.H., D.W.A. Hunt, D.R. Miller and K.N. Slessor. 1986. Orientation in forest Coleoptera: an uncertain outcome of responses by individual beetles to variable stimuli. In T.L. Payne, M.C. Birch and C.E.J. Kennedy (eds.). Mechanisms in insect olfaction. pp. 97-109. Clarendon, Oxford, U.K. 349 p. 
Borden, J.H. and B.S. Lindgren. 1988. Role of semiochemicals in IPM of the mountain pine beetle. In T.L. Payne and H. Saarenmaa (eds.). Integrated control of scolytid bark beetles. pp. 247-255. Virginia Polytechnic Inst. and St. Univ., Blacksburg, Virginia. 355 p. Borden, J.H., I.M. Wilson, R. Gries, L.J. Chong, H.D. Pierce, Jr. and G. Gries. 1998. Volatiles from the bark of trembling aspen, Populus tremuloides Michx. (Salicaceae) disrupt secondary attraction by the mountain pine beetle, Dendroctonus ponderosae Hopkins (Coleoptera: Scolytidae). Chemoecology 8: 69-75.

Borden, J.H., L.J. Chong, G. Gries, R. Gries, D.P.W. Huber, H.D. Pierce, Jr. and I.M. Wilson. 2000. Non-host volatiles as repellents for conifer-infesting bark beetles. US Patent No. 6051612. 18 p.

Borden, J.H., L.J. Chong, G. Gries, R. Gries, D.P.W. Huber, H.D. Pierce, Jr. and I.M. Wilson 2001. Non-host volatiles as repellents for conifer-infesting bark beetles. US Patent No. 6217891. 26 p.

Day, R.W. and G.P. Quinn. 1989. Comparisons of treatments after an analysis of variance. Ecol. Monogr. 59: 433-463.

Gibson, K.E., R.F. Schmitz, G.D. Amman and R.D. Oakes. 1991. Mountain pine beetle response to different verbenone dosages in pine stands of western Montana. USDA For. Serv. Res. Pap. INT-444. $11 \mathrm{p}$.

Huber, D.P.W. and J.H. Borden. 2001. Protection of lodgepole pine from mass attack by mountain pine beetle, Dendroctonus ponderosae, with nonhost angiosperm volatiles and verbenone. Entomol. Exp. Appl. 92: 131-141.

Huber, D.P.W. and J.H. Borden. 2003. Comparative behavioral responses of Dryocoetes confusus Swaine, Dendroctonus rufipennis (Kirby), and Dendroctonus ponderosae Hopkins (Coleoptera: Scolytidae) to angiosperm tree bark volatiles. Environ. Entomol. (in press).

Huber, D.P.W., R. Gries, J.H. Borden and H.D. Pierce, Jr. 1999. Two pheromones of coniferophagous bark beetles found in the bark of non-host angiosperms. J. Chem. Ecol. 25: 805-816.

Huber, D.P.W., R. Gries, J.H. Borden and H.D. Pierce, Jr. 2000. A survey of antennal responses by five species of coniferophagous bark beetles (Coleoptera: Scolytidae) to bark volatiles of six species of angiosperm trees. Chemoecology 10: 103-113.

Hunt, D.W.A. and J.H. Borden. 1990. Conversion of verbenols to verbenone by yeasts isolated from Dendroctonus ponderosae (Coleoptera: Scolytidae). J. Chem. Ecol. 16: 1385-1397.

Hunt, D.W.A., J.H. Borden, B.S. Lindgren and G. Gries. 1989. The role of autoxidation of $\alpha$-pinene in the production of pheromones of Dendroctonus ponderosae (Coleoptera: Scolytidae). Can. J. For. Res. 19: 1275-1282.

Kostyk, B.C., J.H. Borden and G. Gries. 1993. Photoisomerization of antiaggregation pheromone verbenone: Biological and practical implications with respect to the mountain pine beetle, Dendroctonus ponderosae Hopkins (Coleoptera: Scolytidae). J. Chem. Ecol. 19: $1749-1759$.

Leufvén, A., G. Bergström and E. Falsen. 1984. Interconversion of verbenols and verbenone by identified yeasts isolated from the spruce bark beetle Ips typographus. J. Chem. Ecol. 10: 1349-1361.

Lindgren, B.S. and J.H. Borden. 1993. Displacement and aggregation of mountain pine beetles, Dendroctonus ponderosae (Coleoptera: Scolytidae), in response to their antiaggregation and aggregation pheromones. Can. J. For. Res. 23: 286-290.
Lindgren, B.S., J.H. Borden, G.H. Cushon, L.J. Chong and C.J. Higgins. 1989. Reduction of mountain pine beetle (Coleoptera: Scolytidae) attacks by verbenone in lodgepole stands in British Columbia. Can. J. For. Res. 19: 65-68.

Lister, C.K., J.M. Schmid, S.A. Mata, D. Haneman, C. O'Neil, J. Pasek and L. Sower. 1990. Verbenone bubble caps ineffective as a preventive strategy against mountain pine beetle attacks in ponderosa pine. USDA For. Serv. Res. Note RM-501. 3 p.

Maclauchlan, L.E. and J.E. Brooks. 1999. Strategies and tactics for managing the mountain pine beetle, Dendroctonus ponderosae. B.C. For. Serv., Kamloops Region, Kamloops, BC. 57 p.

Pitman, G.B., J.P. Vité, G.W. Kinzer and A.F. Fentiman, Jr. 1969. Specificity of population-aggregating pheromones in Dendroctonus. J. Insect Physiol. 15: 363-366.

Pureswaran, D.S., R. Gries, J.H. Borden and H.D. Pierce, Jr. 2000. Dynamics of pheromone production and communication in the mountain pine beetle, Dendroctonus ponderosae Hopkins, and the pine engraver, Ips pini (Say) (Coleoptera: Scolytidae). Chemoecology 10: 153-168.

Raffa, K.A. and A.A. Berryman, 1983. The role of host plant resistance in the colonization behavior and ecology of bark beetles (Coleoptera: Scolytidae). Ecol. Monogr. 53: 27-49.

Renwick, J.A.A. 1967. Identification of two oxygenated terpenes from the bark beetles Dendroctonus frontalis and Dendroctonus brevicomis. Contrib. Boyce Thompson Inst. 23: 355-360.

Renwick, J.A.A. and J.P. Vité. 1969. Bark beetle attractants: mechanism of colonization by Dendroctonus frontalis. Nature 244: 1222-1223.

Ryker, L.C. and K.L. Yandell. 1983. Effect of verbenone on aggregation of Dendroctonus ponderosae Hopkins (Coleoptera, Scolytidae) to synthetic attractant. Z. angew. Entomol. 96: 452-459. Safranyik, L. T.L. Shore, D.A. Linton and B.S. Lindgren. 1992. The effect of verbenone on disperal and attack of the mountain pine beetle, Dendroctonus ponderosae Hopk. (Coleoptera, Scolytidae) in a lodgepole pine stand. J. Appl. Entomol. 113: 391-397.

Schmitz, R.F. and M.D. McGregor. 1990. Antiaggregative effect of verbenone on response of the mountain pine beetle to baited traps. USDA For. Serv. Res. pap. INT-423. 7 p.

Shea, P.J., M.D. McGregor and G.E. Daterman. 1992. Aerial application of verbenone reduces attack by the mountain pine beetle. Can. J. For. Res. 22: 436-441.

Shore, T.L., L. Safranyik and B.S. Lindgren. 1992. The response of mountain pine beetle (Dendroctonus ponderosae) to lodgepole pine trees baited with verbenone and exo-brevicomin. J. Chem. Ecol. 18: 533-541.

Wilson, I.M., J.H. Borden, R. Gries and G. Gries. 1996. Green leaf volatiles as antiaggregants for the mountain pine beetle, Dendroctonus ponderosae Hopkins (Coleoptera: Scolytidae). J. Chem. Ecol. 22: 1861-1875.

Zar, J.H. 1984. Biostatistical analysis. $2^{\text {nd }}$ ed. Prentice-Hall, Englewood Cliffs, New Jersey. 718 p. 